\title{
Bimetallic nanowire sensors for extracellular electrochemical hydrogen peroxide detection in $\mathrm{HL}-1$ cell culture
}

\author{
Konstantin G. Nikolaev ${ }^{1,2}$, Vanessa Maybeck ${ }^{1}$, Elmar Neumann ${ }^{1}$, Sergei S. Ermakov ${ }^{2}$, Yuri E. \\ Ermolenko $^{2}$, Andreas Offenhäusser ${ }^{1}$, Yulia G. Mourzina ${ }^{1}$ \\ ${ }^{1}$ Institute of Complex Systems ICS-8, Forschungszentrum Jülich GmbH, 52425 Jülich, Germany and \\ JARA-FIT, 52425 Jülich, Germany \\ ${ }^{2}$ Institute of Chemistry, St. Petersburg State University, Universitetskaya nab. 7-9, 198504, St. \\ Petersburg, Russia \\ Corresponding authors: y.mourzina@fz-juelich.de (Dr. Yu. Mourzina) \\ telephone: 49-2461-612364 \\ fax numbers: 49-2461-618733
}

\begin{abstract}
The present study of nanoelectrochemical sensors prepared by directed electrochemical nanowire assembly (DENA) is defined by the requirements of electrochemical analysis, where the transducer function of metallic nanowires is synergetically combined with their electrochemical catalytic activity with respect to a particular analyte. We show for the first time that this technique can be employed for metals $(\mathrm{Pd}, \mathrm{Au})$ and their bimetallic compositions to create various multicomponent sensor nanomaterials on a single chip without the use of multistep lithography for the spatially resolved analysis of solutions. The nanostructures of various compositions can be individually addressed when used in liquid media, so that the particular surface properties of the individual nanoarray elements can be used for the electrochemical analysis of specific analytes. The sensor application of these devices in electrolytes and cell culture conditions has been demonstrated for the first time. As an example, the Pd-Au nanowires prepared by DENA were used for a non-enzymatic analysis of $\mathrm{H}_{2} \mathrm{O}_{2}$ with a linear concentration interval of $10^{-6}-10^{-3} \mathrm{M}$, sensitivity of $18 \mu \mathrm{A} \mathrm{M}^{-1}$ and detection limit of $3 \times 10^{-7} \mathrm{M}$ at as low absolute value of the detection potential as $-0.05 \mathrm{~V}$. This sensor was also proven for the detection of hydrogen peroxide in HL1 cell culture, demonstrating good biocompatibility and support for the cell culture conditions. Using various DENA-grown electrochemical compositions on a single chip, a novel multisensor platform is proposed for the determination of various analytes in electrolyte solutions for biocompatible sensor arrays, flexible multianalyte environmental and technological process monitoring, and healthcare areas.
\end{abstract}


Keywords Directed electrochemical nanowire assembly, nanoelectrochemical sensor, multicomponent, hydrogen peroxide, HL-1 cell culture

\section{Introduction}

The physiological significance of a series of intermediates of oxygen reduction together with a need for better understanding of their generation and utilization in cells and tissue requires the development of devices for their quantification in vivo with high spatial and temporal resolution. From 0.4 to $4 \%$ [1-3] of oxygen consumed by mitochondria produces a 1 -e reduction product superoxide radical anion $\mathrm{O}_{2}{ }^{\bullet-}$ due to electron "leakage" at Complex I (NADH dehydrogenase) and Complex III (ubiquinone-cytochrome $c$ reductase) instead of electron transfer to the next electron carrier in the mitochondrial electron transport chain. Superoxide anion, arising either from the partial reduction of oxygen during aerobic respiration or exposure of cells to a variety of physical, chemical and biological agents $[4,5]$, is a precursor of a series of cytotoxic compounds collectively known as reactive oxygen species (ROS) [6,7] and may lead to a pathophysiological situation termed oxidative stress [6]. This cellular condition with altered redox homeostasis may result in oxidative modifications of cellular macromolecules, impaired physiological functions in cellular proliferation and host defense, activation of specific signaling pathways linked to aging, development of age-related deceases, and cell death $[6,8]$. Some ROS, such as superoxide and hydroxyl radicals, are extremely unstable, while hydrogen peroxide, which is produced by spontaneous $\left(\mathrm{k}=2 \times 10^{5} \mathrm{M}^{-1} \mathrm{~s}^{-1}\right)$ or enzymatic ( $\left.\mathrm{SOD}, \mathrm{k}=2 \times 10^{9} \mathrm{M}^{-1} \mathrm{~s}^{-1}\right)$ dismutation of superoxide is non-charged, freely diffusing, and relatively long-lived [3]. Absolute levels of $\mathrm{H}_{2} \mathrm{O}_{2}$ depend on the balance between $\mathrm{H}_{2} \mathrm{O}_{2}$ generation and the cellular activity of the $\mathrm{H}_{2} \mathrm{O}_{2}$-scavenging enzymes and were reported as $10^{-9}$ to $10^{-7} \mathrm{M}$ [1]. Since it is most stable and accessible for measuring ROS as well as being a signaling molecule, $\mathrm{H}_{2} \mathrm{O}_{2}$ has attracted much interest. Moreover, hydrogen peroxide is a catalytically generated redox-active product of numerous enzymatic reactions used for the determination of glucose, glutamate, lactate, cholesterol, and monoamines. Consequently, $\mathrm{H}_{2} \mathrm{O}_{2}$ quantification becomes a strategy for measuring these target molecules. Thus, the quest for accurate and rapid detection of hydrogen peroxide in bio- and pharmaceutical analysis, clinical diagnostics, as well as technological and environmental monitoring motivated significant research activity in $\mathrm{H}_{2} \mathrm{O}_{2}$ analytical methods [3,5,9-19]. Electrochemical sensor analysis fulfills this function, being an accurate, selective, rapid, low-cost, simple instrumentation, and easy to miniaturize. Improvements in the electrode thermodynamics and kinetics of $\mathrm{H}_{2} \mathrm{O}_{2}$ redox reactions will additionally contribute to the employment of $\mathrm{H}_{2} \mathrm{O}_{2}$ as a carbon-free energy carrier in hydrogen peroxide fuel cells [20]. $\mathrm{H}_{2} \mathrm{O}_{2}$ can be either oxidized or reduced directly at ordinary solid or noble-metalbased transducers. Unfortunately, several studies have demonstrated that these redox processes in ROS 
applications are hindered by slow electrode kinetics and high overpotential, which is responsible for the cooxidation of many electroactive species present in natural samples [5]. To solve this problem, biological molecules and novel nanostructured materials with electrocatalytic properties have been used [5,9,10,1417,21-27]. Enzymes (e.g., horseradish peroxidase) or heme-proteins with intrinsic peroxidase activity can be used for the electrochemical detection of hydrogen peroxide. This method provides electrochemical analysis at low (close to $0 \mathrm{~V}$ vs $\mathrm{Ag} / \mathrm{AgCl}$ ) potentials and demonstrates the sub- $\mu \mathrm{M}$ detection limits. However, the sensitive elements of these sensors includes components, which do not support cell culture growth conditions. Metallic nanomaterials, in particular, metal nanowires, play a key role in the construction of advanced non-enzymatic miniaturized $\mathrm{H}_{2} \mathrm{O}_{2}$ electrochemical sensors, which are based on the catalytic reduction of the $\mathrm{H}_{2} \mathrm{O}_{2}$ on the nanostructured electrode, due to their good stability, sensor miniaturization potential, and excellent electronic and catalytic properties [26,27].

In this work we explore directed electrochemical nanowire assembly (DENA) [28-36] for a novel class of electrochemical sensors defined by the above-mentioned requirements for the electrochemical analysis of solutions. The approach is based on the synergic effect, where the transducer function of metallic nanowires is combined with their electrochemical catalytic activity for a particular analyte. Electrochemically deposited NWs were employed to create gas sensors for $\mathrm{H}_{2}, \mathrm{NH}_{3}$, etc. [37-39]. Important advantages of DENA promising for application in sensors such as spatial resolution, fast growth rate of tens of $\mu \mathrm{m}$ of nanostructures per second, room temperature and atmosphere, and low costs have not been extended to include electrochemical sensors in electrolyte solutions so far.

We demonstrate this approach with palladium-gold bimetallic (Pd-Au) nanowires and dendrites. This alloy has attracted great attention because of its potential application in various technologically important fields due to its unique catalytic, electrocatalytic, and electronic properties, which vary with their metallic ratio. Bimetallic $\mathrm{Pd}-\mathrm{Au}$ nanowires and dendrites often exhibit enhanced catalytic performance in terms of activity, selectivity, and stability, compared to the separate components [40,41]. We validated these bimetallic nanowires not only with test samples of known concentrations of hydrogen peroxide, but also in cell culture conditions with the cardiomyocyte-like cell line HL-1 [42]. HL-1 cells are derived from a mouse atrial tumor and though they continue to multiply in culture, they mature into contractile tissue when confluent. Despite their continually dividing state, various studies have shown similarities between HL-1 cells and primary cardiomyocytes, including in studies of hypoxia [43]. The high metabolism of these cells provides a good system for ROS generation upon re-oxygenation after hypoxia.

\section{Experimental section}

\section{Reagents}


Gold (III) chloride trihydrate, potassium tetrachloropalladate (II), palladium (II) chloride, HEPES (4-(2hydroxyethyl)-1-piperazineethanesulfonic acid), hydrogen peroxide $\geq 30 \%$ (for ultratrace analysis), disodium phosphate, sodium dihydrogen phosphate, acetone, propanol, and other chemicals employed in the synthesis and for electrochemical measurements were purchased from Sigma-Aldrich with analytical grade purity and were used as received. The reagents for the photolithography processes were supplied by MicroChem Corp. and MicroChemicals GmbH. All solutions were prepared using distilled or deionized water (Merck Millipore: Milli-Q Advantage A10 Ultrapure Water Purification System). The HL-1 growth medium was Claycomb Medium [42] (Thermo Fisher) supplemented with $10 \% \mathrm{v} \mathrm{v}^{-1}$ fetal bovine serum (Invitrogen), $0.1 \mathrm{mM}$ norepinephrine, $100 \mu \mathrm{g} \mathrm{mL} \mathrm{m}^{-1}$ penicillin-streptomycin (Invitrogen), and $2 \mathrm{mM}$ L-glutamine. The measurement medium was phosphate-buffered saline $(\mathrm{NaCl} 137 \mathrm{mM}, \mathrm{KCl}$ $2.7 \mathrm{mM}, \mathrm{Na}_{2} \mathrm{HPO}_{4} 8 \mathrm{mM}, \mathrm{KH}_{2} \mathrm{PO}_{4} 1.8 \mathrm{mM}$ ) adjusted to the osmolarity of HL-1 growth medium with glucose (PBS + glucose).

\section{Apparatus}

Electrodes for the interconnection process were prepared in an ISO 5 cleanroom. The silicon oxide layer was deposited on the wafer using a Tempress oxidation furnace. The wafer was covered by metals with a Balzers (Pfeiffer) PLS 500 thin film vapor deposition machine. The photolithography process was performed with the Mask Aligner Süss MA-6 (Hg-vapor lamp 350W). For the structural characterization of the nanostructures and electrodes, a scanning electron microscope Magellan ${ }^{\mathrm{TM}}$ XHR SEM was used with an EDX detector system, and a Magellan ${ }^{\mathrm{TM}}$ XHR SEM with a focused ion beam (FIB) system. The optical microscope Leica DMLB was used for visualization and position fixing. The nanowires and dendrites were grown using an Agilent Trueform Series Waveform Generator (33600 Series, Higher Frequency Model).

Electrical characterization of the assembled nanowires were performed at a Keithley semiconductor analyzer (model 4200 SCS). All electrochemical measurements were performed using a potentiostat-galvanostat AUTOLAB PGSTAT302. The electrochemical cell included a miniature silver/silver chloride reference electrode (Ag/AgCl, $3 \mathrm{M} \mathrm{KCl,} \mathrm{DRIREF-450,} \mathrm{World} \mathrm{Precision}$ Instruments), a coiled platinum auxiliary electrode, and the desired working electrode. The oxygen was removed by purging the solutions and electrochemical cell with argon. The measurements were performed at room temperature $22 \pm 1{ }^{\circ} \mathrm{C}$. A PDMS lid with openings for the platinum counter and reference electrodes and gas supply was constructed to cover the electrochemical cell.

\section{Electrode preparation}


The 4-inch boron-doped n-Si (111) wafer was covered by a $1 \mu \mathrm{m} \mathrm{SiO} 2$ layer, Figures $\mathrm{S} 1$ and $\mathrm{S} 2$. The wafer was kept at $180{ }^{\circ} \mathrm{C}$ on a hot plate for dehydration for $20 \mathrm{~min}$ before the photoresist coating process. Then the wafer was first coated with $5 \mu \mathrm{m}$ of the LOR 3B $(2.5 \mathrm{~mL})$ in the spin-coater $(3000 \mathrm{rpm}, 35 \mathrm{~s})$ for undercut control. After baking for $5 \mathrm{~min}$, the wafer was coated with $2 \mu \mathrm{m}$ of the AZ nLOF $2020(2.5$ $\mathrm{mL}, 3000 \mathrm{rpm}, 35 \mathrm{~s}$ ). After this procedure, the coated wafer was pre-baked on the hot plate at $115^{\circ} \mathrm{C}$ for $90 \mathrm{~s}$. The wafer was exposed for $1.4 \mathrm{~s}$ at $325 \mathrm{~W}$ using a photolithography mask, Figure S2. After that, the wafer was post-exposure baked at $115^{\circ} \mathrm{C}$ for $90 \mathrm{~s}$ and developed by AZ®326 (MIF, 2.38\% TMAH in $\mathrm{H}_{2} \mathrm{O}$ ) for $1 \mathrm{~min}$. The wafer coated with structured polymer layers was metallized with gold. The Au layer was $100 \mathrm{~nm}$ thick, and was deposited on the $10 \mathrm{~nm}$ adhesion layer of the Ti. After metallization, the wafer was lifted off with acetone. Finally, the wafers were washed with isopropanol.

These wafers were further used for the DENA of metals and metal compositions.

For use in the electrolyte solutions, the growth electrodes and contact lines were isolated by polyimide polymer via a photolithography process. After photolithography, only channels with the DENA-grown nanowires were open for contact with the electrolyte solution and bond pads were open for contact to the external circuitry. The wafers were then diced into $13 \times 13 \mathrm{~mm}$ chips. Glass rings or funnels (radius $8 \mathrm{~mm}$ ) were glued to the chips to accommodate the electrolyte solution or cell culture medium for the HL-1 cell culture and electrochemical experiments, leaving the bond pads outside the glass ring.

\section{HL-1 cell culture}

The HL-1 cell line was maintained in T25 flasks at $37^{\circ} \mathrm{C}$ and $5 \% \mathrm{CO}_{2}$ until they were passed on to the sensor chips. The supplemented HL-1 medium was exchanged every day. When the cells reached confluency and visibly contracted, the flasks were treated with $0.05 \%$ trypsin/EDTA for 5 min to release cells. Suspended cells were pelleted by centrifugation, resuspended in growth medium and distributed to new substrates. Sensor chips were prepared by sterilization with UV light for 1 hour. The polyimide areas of the chips next to the sensors were coated for 1 hour with fibronectin/gelatin then rinsed with Milli-Q to improve adhesion of the cells to the surface. To plate cells onto the sensor arrays, the cells were suspended in $100 \mu \mathrm{L}$ of medium and the drop was centered on the array. After 1 hour in culture, during which the cells settled and adhered to the surface, the full culture volume was made up with growth medium. Chips were incubated at $37{ }^{\circ} \mathrm{C} 5 \% \mathrm{CO}_{2}$ for one to two days. Cells were fed by completely exchanging the growth medium once a day.

The growth medium was exchanged with PBS ( $\mathrm{NaCl} 137 \mathrm{mM}, \mathrm{KCl} 2.7 \mathrm{mM}, \mathrm{Na}_{2} \mathrm{HPO}_{4} 8 \mathrm{mM}$, $\left.\mathrm{KH}_{2} \mathrm{PO}_{4} 1.8 \mathrm{mM}\right)+$ glucose for measurements. Cell vitality was confirmed after experiments of up to 3 hours' duration by staining live cells for $5 \mathrm{~min}$ with $1 \mu \mathrm{M}$ calcein-AM in growth medium. 


\section{Results and discussion}

Figure 1 shows examples of $\mathrm{Au}(1 \mathrm{~b}), \mathrm{Pd}(1 \mathrm{c})$, and $\mathrm{Pd}-\mathrm{Au}$ (1d) nanowires and nanodendrites electrochemically assembled on a single chip. The growth electrodes (source and ground electrodes) for directional growth and contacting the nanowires and nanodendrites to the external circuitry were prepared by photolithography (details of the photolithography process and a video of the nanowire assembly are provided in supporting information) and consisted of a $10 \mathrm{~nm}$ Ti adhesion layer and $100 \mathrm{~nm}$ Au top layer deposited on a $1 \mu \mathrm{m} \mathrm{SiO}_{2}$ insulating layer on a silicon substrate. The gap between the growth electrodes was 20 or $50 \mu \mathrm{m}$.

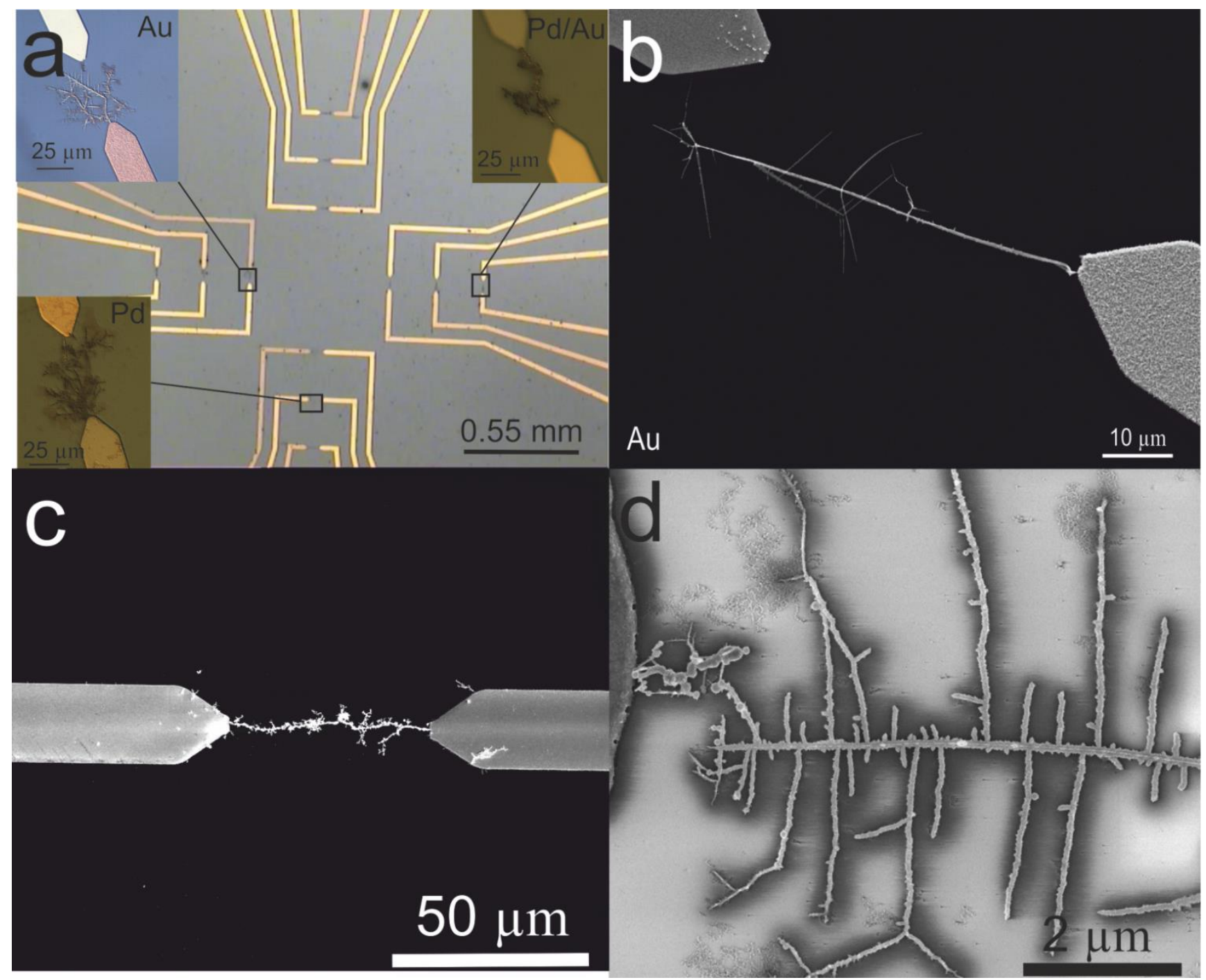

Fig. 1 a Microscopy image of a chip with photolithographically prepared growth electrodes, contact lines, contact pads, and the DENA-grown $\mathrm{Au}, \mathrm{Pd}$, and $\mathrm{Pd}-\mathrm{Au}$ nanowires and nanodendrites on a single $13 \times 13$ mm chip. Examples of SEM images of (b) Au, (c) Pd, and (d) Pd-Au nanowires and nanodendrites on a chip prepared under different conditions 
The DENA method suggested by Ozturk et. al. [28,34,35] is based on inducing directional electrochemical deposition in simple metal salt solutions to produce metallic wires and like the dielectrophoretic assembly [44] enables the single-step growth and interconnection of the wires which vary in their conductance by $\pm 10 \%$ [45] with the targeted points in the external circuitry. The AC electrodeposition methods dielectrophoresis and DENA have become available for a number of materials, such as gold [28,31,34], indium [29], platinum [33,44], palladium [32,46], and Au-Pt [30,47], Au-Ag [48], Au-Pd [49] alloys. Ozturk et al. [35] proposed dendritic solidification, a diffusion-limited process, as important mechanism in the DENA growth process [50]. According to this, the dendritic crystals grow with a fixed tip radius and velocity along the particular crystallographic direction. The growth velocity depends on the square root of the applied AC frequency, and increases linearly with the bulk concentration of the electrolyte, while the tip radius is anti-correlated with the frequency [34]. Thereby, both growth velocity and the diameter of the dendrites can be tuned by the concentration and frequency.

Ozturk et al. [34,35] investigated the influence of the concentration and AC voltage frequency. Nanowire diameters decreased from several $\mu \mathrm{m}$ to about $40 \mathrm{~nm}$ with increasing frequency of the AC voltage up to $50 \mathrm{MHz}$. The growth velocity was found to increase linearly in the concentration range of the metal salt from 10 to $60 \mathrm{mM}[35]$.

The relation between growth velocity and tip radius was further investigated by Kawasaki et al [33]. The authors found that increasing the AC frequency increased the growth velocity and decreased the wire radius. The observation that the growth velocity and the wire radius are anticorrelated is in agreement with dendritic solidification theory. The amount of branches on the nanowires became less with increasing ionic strength due to the addition of $\mathrm{NaCl}$ to the deposition solution.

The relationship between the tip radius and the AC frequency was later discussed by Nerowski et al. [44,51] for growing nanowires by dielectrophoresis and Ozturk et al. [34,35] for DENA. Thus, two effective models were proposed for successful nanowire interconnection: a model with triangulare-end shaped growth electrodes (with less resistance) [34], and a model with a spherical and cylindersymmetrical shape of the growth electrodes [44]. The electrode gap in the studies varied between 2-10 $\mu \mathrm{m}[44,48]$ and $60 \mu \mathrm{m}[47,30]$. This distance could be explained by the preparation technique for the growth electrodes. The photolithography method was used in the all studies described above. For this method, a distance of 2-10 $\mu \mathrm{m}$ between the growth electrodes is critical and gives rise to large errors for the electrode gap and geometry. Nevertheless, the growth electrode gap is an important factor for the DENA technique, since the shorter the distance between the electrodes, the lower the potential gradient required to initiate the nanowire growth.

Thus with decreasing radius of the growth electrodes and concentration of the deposition solution, nanowires with a smaller diameter and a lower contact resistance [34] could be synthesized with 
increasing $\mathrm{AC}$ voltage frequency. Besides the noble metals described above, palladium and nickel are prospective for the nanowire alloys compositions because these metals decrease the contact resistances $[52,53]$ and improve the desorption processes of contaminants at surfaces [54].

The source and ground electrodes prepared by photolithography (SI and Figures S1,2) were connected to the AC/DC high frequency voltage generator (Agilent Trueform Series Waveform Generator 33600). A $5 \mu \mathrm{L}$ droplet of the metal salt solution was placed across the electrodes. Solutions of the metal salts were: $1 \times 10^{-3}$ to $1 \times 10^{-2} \mathrm{M} \mathrm{HAuCl}_{4}$ for the Au NWs; $1 \times 10^{-2} \mathrm{M} \mathrm{Pd}(\mathrm{ac})_{2}$ or $\mathrm{PdCl}_{2}$ in $\mathrm{PBS}(\mathrm{pH} 8$ ) for the $\mathrm{Pd} \mathrm{NWs} ; 5 \times 10^{-3} \mathrm{M} \mathrm{HAuCl}_{4}$ and $5 \times 10^{-3} \mathrm{M} \mathrm{PdCl}_{2}$ in PBS (pH 8) for the Pd-Au NWs, Table 1.

Table 1 The experimentally optimized parameters for nanowire growth

\begin{tabular}{|c|c|c|c|c|}
\hline Metal / alloy & $\begin{array}{c}\text { AC } \\
\text { voltage / V }\end{array}$ & $\begin{array}{c}\text { DC } \\
\text { voltage / V }\end{array}$ & $\begin{array}{c}\text { Frequency / } \\
\text { MHz }\end{array}$ & Solution composition \\
\hline $\mathrm{Pd}$ & 17 & 1.5 & 45 & $10^{-2} \mathrm{M} \mathrm{K}_{2} \mathrm{PdCl}_{4}$ water solution \\
\hline $\mathrm{Pd}$ & 17 & 1.5 & 38 & $10^{-2} \mathrm{M} \mathrm{PdCl}_{2}$ in $\mathrm{PBS}(\mathrm{pH} 8)$ \\
\hline $\mathrm{Au}$ & 18 & 1.0 & 45 & $10^{-2} \mathrm{M} \mathrm{HAuCl}_{4}$ water solution \\
\hline $\mathrm{Pd}-\mathrm{Au}$ & 17 & 1.5 & 38 & $5 \times 10^{-3} \mathrm{M} \mathrm{HAuCl}_{4}, 5 \times 10^{-3}$ \\
\hline & & & & $\mathrm{PdCl}_{2}$ dissolved in PBS (pH 8) \\
\hline
\end{tabular}

Growth was achieved by applying a square wave potential, V (t), of the desired frequency and a DC voltage offset across the gap. The square wave was selected as a wave form for nanowire preparation $[28,29]$. With a sine waveform, no nanowire growth was observed under the same conditions. We examined growth in a range of frequencies 38 - $50 \mathrm{MHz}$ and applied AC voltages of 17 - $18.5 \mathrm{Vpp}$ (peak to peak), Table 1. At frequencies higher than $50 \mathrm{MHz}$, the square waveform is transformed into a sine waveform, thus stopping the nanowire growth process. The $\mathrm{AC}$ voltage values were chosen as a consequence of the maximal waveform generator resolution and they depend on the electrode gap. A duty cycle of $50 \%$ was adjusted in all experiments. The DC voltage applied to the source electrode was in the range from +1.0 to $+1.5 \mathrm{~V}$. It is important to note that the $\mathrm{DC}$ voltage was found experimentally by reference to the theoretical deposition potentials of the respective metals. In the case of alloy deposition, the DC voltage was applied according to the metal with a more negative reduction potential [55], which requires a higher DC offset, Table 1. The DC voltage signal was modulated by shifting up the AC voltage oscillation window in the positive voltage area. With this arrangement, nanowire growth was reproducibly initiated from the ground electrode. Without application of the DC voltage signal, the nanowire growth was random and required a prolonged initiation stage. These conditions initiated and drove the reduction of metal ions resulting in the growth of nanowires and dendrites from the ground to the source electrode 
$[33,37]$. The growth process was observed in situ under an optical microscope (Leica DMLB, a video of the nanowire assembly is provided in the SI) until the nanowires connected an opposite (source) electrode producing an interconnection for further measurement of the conductance. After growth of nanowires of one metal or metal combination, the chip was thoroughly rinsed with distilled water, a new solution was applied between another pair of electrodes and the growth procedure was repeated until all pairs of electrodes were connected by nanowires of the desired compositions. Finally, the chip was washed with distilled water several times, dried, and characterized by scanning electron microscopy, EDX analysis, and conductivity measurements.

Depending on the concentration of the metal salts, electrode gap, and also the deposition conditions, the nanostructures varied in shape and compositions, as shown for example in Figures 1 and 2.

Figure $2 \mathrm{~b}$ shows an example of a Pd NW deposited from $10^{-1} \mathrm{M} \mathrm{Pd}(\mathrm{ac})_{2}$ solution at $39 \mathrm{MHz}, 18$ Vpp and 1.8 V DC offset. The nanowire obtained has a diameter of about $800 \mathrm{~nm} . \operatorname{Pd}(\mathrm{ac})_{2}$ solution has an impact on the composition of the deposited structure. The EDX spectrum, Figure 2a, shows that this $\mathrm{Pd}$ nanowire has no essential admixtures except for carbon. Acetate was a possible source of carbon, which was co-deposited together with palladium [32]. Carbon co-deposition is not a desirable process in metal deposition, since it leads to the increase of resistance and a lower electroactive surface area of the metal electrodes. Therefore, we further used a $10^{-2} \mathrm{M} \mathrm{K}_{2} \mathrm{PdCl}_{4}$ water solution for the synthesis of the $\mathrm{Pd}$ nanostructures. The EDX spectrum of the Pd dendrites obtained at $45 \mathrm{MHz}, 17 \mathrm{Vpp}$ and $1.5 \mathrm{~V}$ DC offset in $\mathrm{K}_{2} \mathrm{PdCl}_{4}$ solution proved $\mathrm{Pd}$ deposition, Figure $\mathrm{S} 3$. The problem of carbon co-deposition could thus be minimized by acetate counter-ion substitution with a Pd water-soluble complex $\mathrm{K}_{2} \mathrm{PdCl}_{4}$. In summary, we synthesized Pd nanowires and dendrites with a diameter from 200 to $800 \mathrm{~nm}$ interconnecting electrode gaps of 50 and $20 \mu \mathrm{m}$. A series of EDX analyses proved that the Pd nanostructures have surfaces free from essential impurities. 


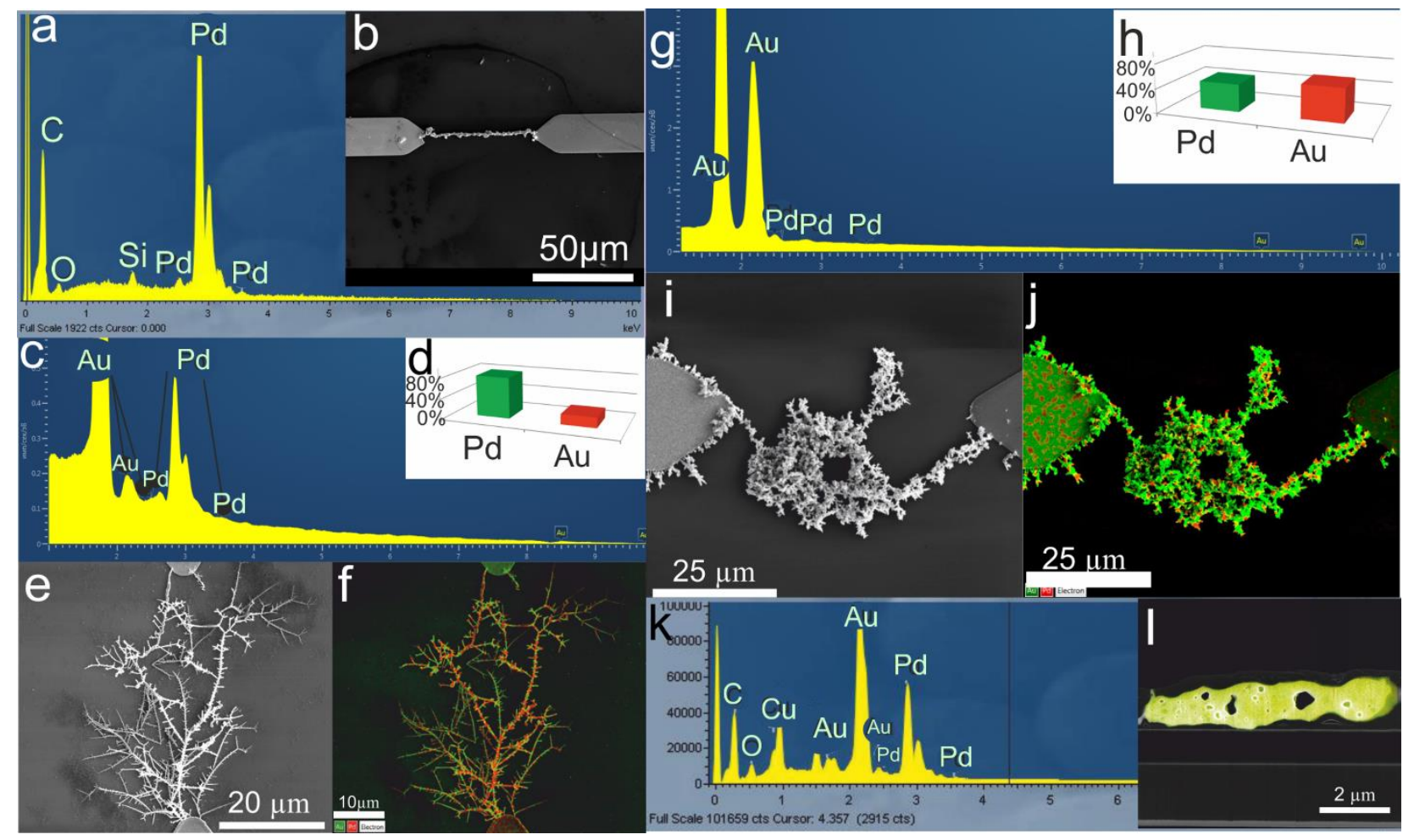

Fig 2 a EDX spectrum of a Pd NW electrode shown in (b) SEM micrograph. The nanostructure was synthesized by deposition from a $\mathrm{Pd}(\mathrm{ac})_{2}$ solution. $\mathbf{c}$ EDX spectrum of the Pd-Au nanodendrite electrode and (d) histogram of the ratio of $\mathrm{Pd}$ and $\mathrm{Au}$ in the alloy of the Pd-Au nanodendrite shown in the (e) SEM micrograph. f SEM micrograph of the same Pd-Au nanodendrite electrode with element mapping (Pd green, $\mathrm{Au}$ - red). The structures were synthesized in a water solution of $5 \times 10^{-3} \mathrm{M} \mathrm{HAuCl}_{4}$ and $5 \times 10^{-3} \mathrm{M}$ $\mathrm{K}_{2} \mathrm{PdCl}_{4}$ at $45 \mathrm{MHz}, 17 \mathrm{Vpp}$ and $1.5 \mathrm{~V}$ DC offset. $\mathbf{g}$ EDX spectrum of the Pd-Au alloy and (h) histogram of the ratio of $\mathrm{Pd}$ and $\mathrm{Au}$ in the $\mathrm{Pd}-\mathrm{Au}$ nanodendrite electrode shown in the (i) SEM micrograph. $\mathbf{j}$ EDX map of the same Pd-Au structure (Pd - green, Au - red). $\mathbf{k}$ EDX map of the lamella (cross section) of the $\mathrm{Pd}-\mathrm{Au}$ nanowire, copper is due to the sample holder for the lamella preparation. I EDX mapping of the same lamella of the Pd-Au nanowire. The structures were synthesized by deposition from a solution of $5 \times 10^{-3} \mathrm{M} \mathrm{HAuCl}_{4}$ and $5 \times 10^{-3} \mathrm{M} \mathrm{PdCl}_{2}$ dissolved in PBS (pH 8) at $38 \mathrm{MHz}, 17 \mathrm{Vpp}$ and $1.5 \mathrm{~V}$ DC offset

The DENA technique allows an interconnection between the growth (ground and source) electrodes by the developed metallic and bi-metallic surfaces, Figures 2 and 3. Figure 2 shows two examples of the Pd-Au alloy. The first Pd-Au alloy, Figures $2 \mathrm{c}-\mathrm{f}$, was deposited from $5 \times 10^{-3} \mathrm{M} \mathrm{HAuCl}_{4}$ and $5 \times 10^{-3} \mathrm{M} \mathrm{K}_{2} \mathrm{PdCl}_{4}$ water solution at $45 \mathrm{MHz}, 17 \mathrm{Vpp}$ and $1.5 \mathrm{~V}$ DC offset. Pd accounted for about $60 \%$ in this alloy. The second example, Figur $2 \mathrm{~g}-1$, was obtained by deposition from a solution of $5 \times 10^{-3}$ $\mathrm{M} \mathrm{HAuCl}_{4}$ and $5 \times 10^{-3} \mathrm{M} \mathrm{PdCl}_{2}$ dissolved in PBS (pH 8) at $38 \mathrm{MHz}, 17 \mathrm{Vpp}$, and $1.5 \mathrm{~V} \mathrm{DC}$ offset. The EDX map and spectra, Figures 2g-1, show the homogeneous distribution of both (Au and Pd) elements throughout the length and cross section of the dendrites. The element ratio was $44.5 \%$ and $55.5 \%$ for $\mathrm{Pd}$ 
and $\mathrm{Au}$, respectively. Deposition from a solution of $5 \times 10^{-3} \mathrm{M} \mathrm{HAuCl}_{4}$ and $5 \times 10^{-3} \mathrm{M} \mathrm{K}_{2} \mathrm{PdCl}_{4}$ under the same conditions as described above, but with a frequency of $40 \mathrm{MHz}$, led to a final alloy element composition of $30 \%$ of $\mathrm{Pd}$ and $70 \%$ of $\mathrm{Au}$, Figure 3.
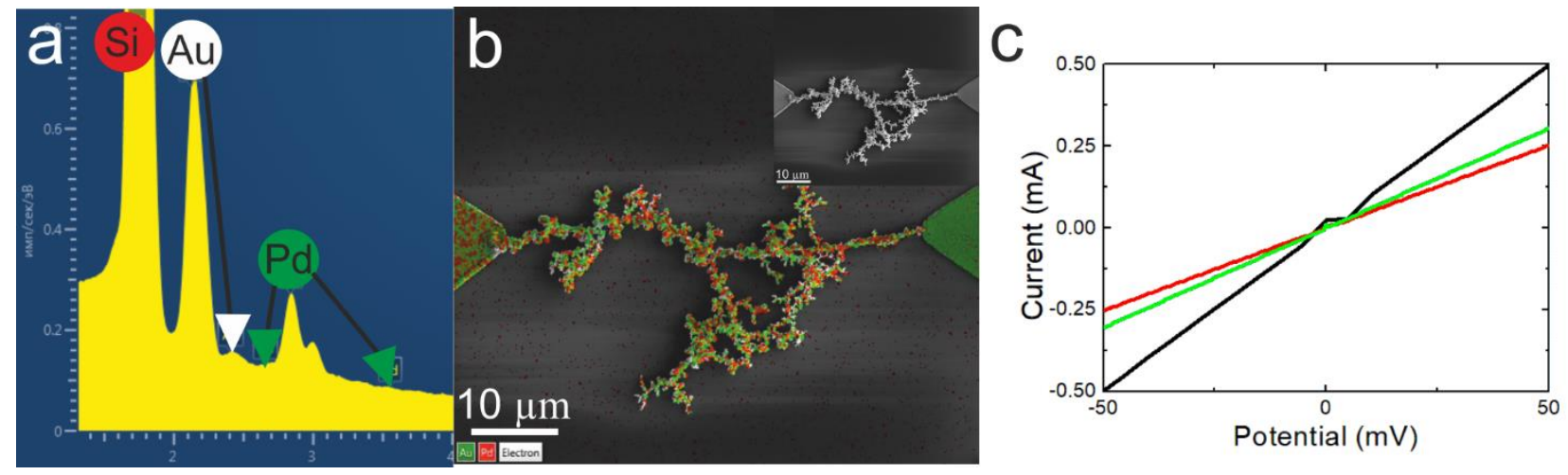

Fig. 3 a EDX spectrum of the Pd-Au alloy. b EDX map of the Pd-Au structure (Pd - green, Au - red), insert in (b) shows an SEM micrograph of the Pd-Au dendrite. The structure was synthesized in a water solution of $5 \times 10^{-3} \mathrm{M} \mathrm{HAuCl}_{4}$ and $5 \times 10^{-3} \mathrm{M} \mathrm{K}_{2} \mathrm{PdCl}_{4}$ at $40 \mathrm{MHz}, 17 \mathrm{Vpp}$ and $1.5 \mathrm{~V} \mathrm{DC}$ offset. c Examples of I-V measurements for $\mathrm{Au}$ (red line), $\mathrm{Pd}$ (black line), and $\mathrm{Pd}-\mathrm{Au}$ (green line) nanostructured interconnections prepared by DENA. Conditions for Pd-Au NWs growth are presented in Table 1. Electrode gap is $50 \mu \mathrm{m}$

The assembled nanowires were electrically characterized by a Keithley semiconductor analyzer. The leads were electrically contacted through the bond pads using tungsten needles. The main electrical characterization was based on a two-point probe measurement, where DC voltages were applied and the resulting currents were measured, i.e. current-voltage (I-V) measurements (DC bias). The resistivities of the nanowires were then calculated from the I-V curves. The sizes of the nanowires were calculated from the SEM data. The contact resistance was not considered in the calculations. It should be noted, however, that the resistivity values found for the metal and alloy nanowires in our work depend on the quality of the contacts between the wire and the growth electrodes produced during the growth as well as on the wire integrity itself. Therefore, the smoothness of the surface and the error-free geometry of the growth microelectrodes produced by photolithography and metal deposition technique may contribute to the standard deviation of the data due to the influence of nanogeometry at the growth ends on the field strength and material diffusion during the nanowire growth.

The results in Figure 3 and Table 2 show that the nanowires of pure metals and Pd-Au alloy demonstrate ohmic behavior and resistivities close to the data for the bulk metals. Thus, the proposed method is not hindered by the co-deposition of organic stabilizing molecules on contacts, as for example in the case of the chemical synthesis of nanostructures [56]. Moreover, the prepared nanowires have 
diameters larger than the mean free pathway of the electron in metals and do not have the high resistivity of ultrathin nanowires, which resulted in the potential drop along the nanowire electrodes in voltammetry [57]. Consequently, the prepared nanostructures can be used as electrodes for electrochemical sensors.

Table 2 Experimental $\left(\rho_{\text {calc }}\right)$ specific resistivity for the metal and Pd-Au alloy nanowires and specific resistivity of bulk metals ( $\left.\rho_{\text {bulk }}\right)$

\begin{tabular}{ccc}
\hline $\begin{array}{c}\text { Metal } / \\
\text { alloy }\end{array}$ & $\rho_{\text {calc }^{\mathrm{a}} / \Omega \mathrm{m},\left(\mathrm{SD}^{\mathrm{b}}\right)}$ & $\begin{array}{c}\rho_{\text {bulk }} / \\
\Omega \mathrm{m}\end{array}$ \\
\hline $\mathrm{Pd}$ & $6.3 \times 10^{-8}\left(1.2 \times 10^{-8}\right)$ & $9.76 \times 10^{-8 \mathrm{c}}$ \\
$\mathrm{Au}$ & $3.8 \times 10^{-7}\left(0.5 \times 10^{-7}\right)$ & $2.44 \times 10^{-8 \mathrm{~d}}$ \\
$\mathrm{Pd}-\mathrm{Au}$ & $1.0 \times 10^{-7}\left(0.1 \times 10^{-7}\right)$ & -
\end{tabular}

\footnotetext{
${ }^{\mathrm{a}}$ For different NW electrodes grown on the same chip, under the same conditions and the optical control of the formation of the contacts between the NWs and the growth electrodes under the microscope during the NW growth

${ }^{\text {b }} \mathrm{SD}$ - standard deviation of $\rho_{\text {calc }}$ for $\mathrm{n}=5$, where $\mathrm{n}$ is the number of nanowires of each composition c [58], d [59]
}

Therefore, in a further step, metallic growth electrodes and contact leads, Figure S1, S2, were isolated by polyimide polymer via a photolithography process (see SI for details) leaving only bond pads and the DENA-prepared nanowires open to the environment for the electrochemical measurements. All electrochemical measurements were performed in a $100 \mu \mathrm{L}$ cell with a three-electrode setup (see SI for details). A photograph of the measurement cell is provided in Figure S4.

After isolation and wafer dicing, the electrodes were first cleaned and preliminarily characterized by cyclic voltammetry in a $0.1 \mathrm{M}$ PBS ( $\mathrm{pH} 7.2$ ), Figure 4. These measurements allowed those nanowire electrodes to be excluded whose connections between the NWs and the external circuitry had been destroyed and additionally proved the presence of metals in the NWs according to their reduction and oxidation potentials. These reduction potentials were $-0.07 \mathrm{~V}$ for $\mathrm{Pd}$ and $+0.48 \mathrm{~V}$ for Au nanowires (vs $\mathrm{Ag} / \mathrm{AgCl}$ (3 M KCl), 0.1 M PBS, pH 7.2), respectively, Figure 4. As shown in Figure 4, the reduction potentials of $\mathrm{Pd}$ and $\mathrm{Au}$ in $\mathrm{Pd}-\mathrm{Au}$ alloy migrated to $-0.12 \mathrm{~V}$ and $0.05 \mathrm{~V}$, respectively. These potentials depend on the reduction potential and concentration of each metal in the alloy [60]. Additionally, the electrochemically active surface area can be estimated using the charge associated with the surface oxide reduction peak assuming a monolayer oxide formation in the anodic scan in $0.1 \mathrm{M} \mathrm{H}_{2} \mathrm{SO}_{4}$ from the baseline-corrected peaks [23]. For example, the electrochemically active surface areas of a $\mathrm{Au}$ nanoelectrode and a $\mathrm{Pd}$ nanoelectrode, Figure S5, were $1.5 \times 10^{-4} \mathrm{~cm}^{2}$ and $1.9 \times 10^{-4} \mathrm{~cm}^{2}$, respectively. It should be emphasized that the electrodes with branched structure (not single nanowires) were preferably used for the electrochemical sensor application since they provide electrocatalytic sites and larger 
electrochemically active surface areas. Hydrogen peroxide detection was performed in the deaerated 0.1 M PBS (pH 7.2) solutions. Figure 4c shows the CVs obtained in the presence of $0 \mathrm{mM}$ (black line) and $10 \mathrm{mM}$ (red line) of $\mathrm{H}_{2} \mathrm{O}_{2}$ on the $\mathrm{Pd}-\mathrm{Au}$ nanodendrite electrode. The red line (Figure 4c) corresponds to the cathodic current of hydrogen peroxide reduction with a half-wave potential of about $-0.125 \mathrm{~V}$. The enhanced electrochemical activities with respect to hydrogen peroxide may be attributable to the excellent electrocatalytic activity of the $\mathrm{Pd}-\mathrm{Au}$ nanodendrite electrode. This allows us to perform determinations at smaller absolute potential values than in previous studies on both the Pd-Pt alloy at $-0.15 \mathrm{~V}$ [61] and pure palladium nanostructures at $-0.4 \mathrm{~V}[62]$.
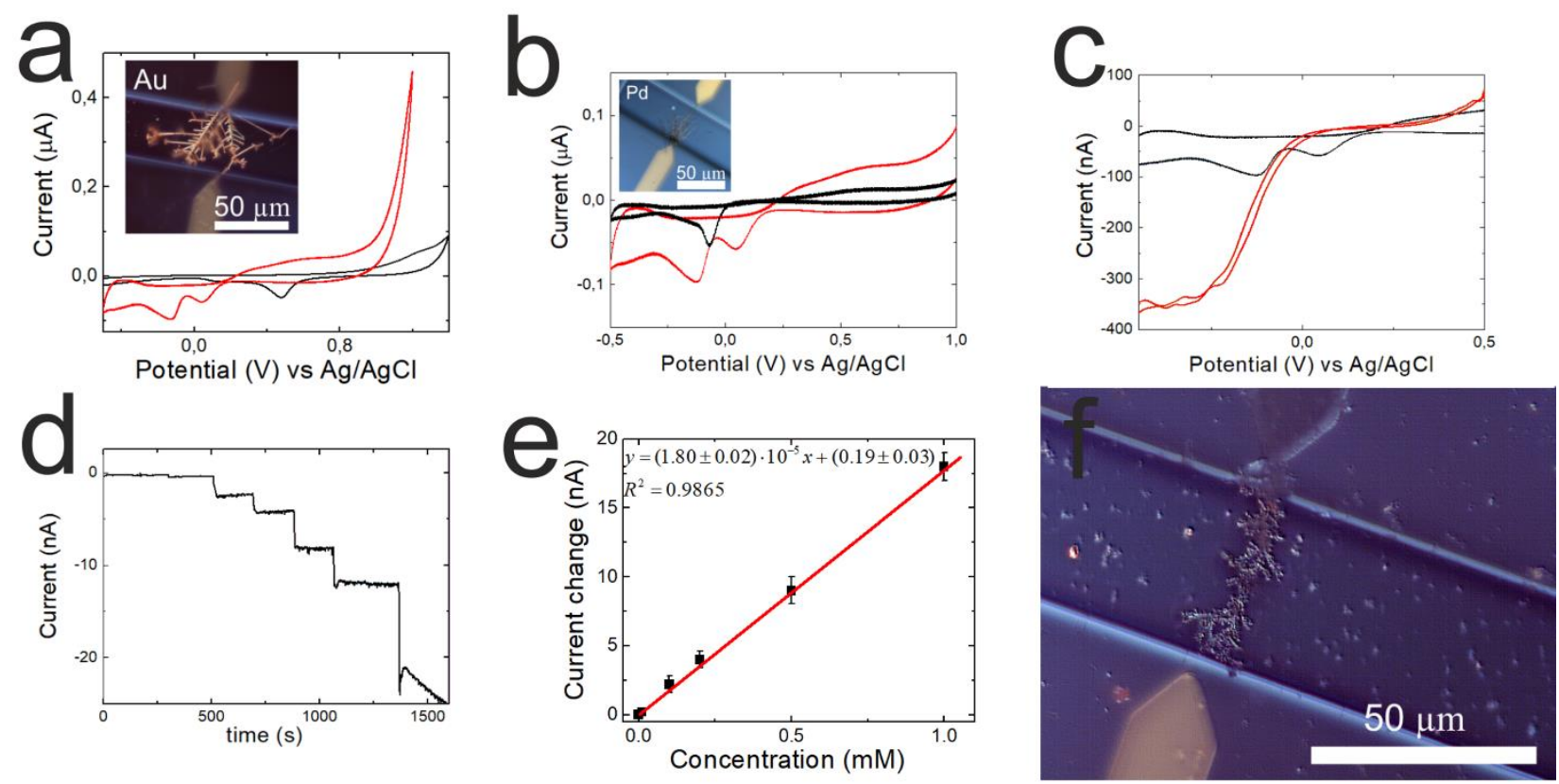

Fig. 4 a CVs of the Au (black line) and Pd-Au (red line) nanowires in 0.1 M PBS (pH 7.2). b CVs of the $\mathrm{Pd}$ (black line) and Pd-Au (red line) nanowires in 0.1 M PBS (pH 7.2). c CVs on the Pd-Au nanodendrite electrode in 0.1 M PBS (pH 7.2) at $0 \mathrm{mM}$ (black line) and $10 \mathrm{mM} \mathrm{H}_{2} \mathrm{O}_{2}$ (red line). d Chronoamperogram with $\mathrm{H}_{2} \mathrm{O}_{2}$ additions in $0.1 \mathrm{M} P B S(\mathrm{pH} 7.2)$ at $-0.05 \mathrm{~V} . \mathrm{H}_{2} \mathrm{O}_{2}$ concentration in the final solution was $10^{-3}$ M. e Average $\mathrm{H}_{2} \mathrm{O}_{2}$ calibration curve of the proposed sensor in $0.1 \mathrm{M}$ PBS ( $\mathrm{pH} 7.2$ ) at $-0.05 \mathrm{~V}$. Error bars are $98.65 \%$ confidence limits. f Microscopy image of the $\mathrm{Pd}-\mathrm{Au}$ nanodendrite electrode prepared by DENA and used for the measurements

Nevertheless, we further set the detection potential to $-0.05 \mathrm{~V}$. This lower potential satisfies the sensitivity and the demand for possible lower detection potentials for biological samples. As shown in Figure $4 \mathrm{~d}$ and e, amperometric detection of the hydrogen peroxide at the $\mathrm{Pd}-\mathrm{Au}$ nanodendrite electrode shown in Figure 4f, was carried out at $-0.05 \mathrm{~V}$. A corresponding calibration curve obtained for the reduction peak current of $\mathrm{H}_{2} \mathrm{O}_{2}$ against the $\mathrm{H}_{2} \mathrm{O}_{2}$ concentration, Figure 4e, shows that the sensor exhibits a wide linear range of $10^{-6} \mathrm{M}$ to $10^{-3} \mathrm{M}$ at this detection potential. Sensitivity of the nanosensor was as 
high as $18 \mu \mathrm{A} \mathrm{M}^{-1}$ at $-50 \mathrm{mV}$ (vs $\left.\mathrm{Ag} / \mathrm{AgCl}(3 \mathrm{M} \mathrm{KCl}), 0.1 \mathrm{M} \mathrm{PBS}, \mathrm{pH} 7.2\right)$. The limit of detection was $3 \times 10^{-7} \mathrm{M}(\mathrm{S} / \mathrm{N}=3)$. Additions of $0.1 \mathrm{mM}$ dopamine, $0.5 \mathrm{mM}$ uric acid, and $0.15 \mathrm{mM}$ ascorbic acid diminish the sensor response to $1 \mu \mathrm{M} \mathrm{H}_{2} \mathrm{O}_{2}$ to less than $50 \%$, Figure $\mathrm{S} 6$. The analytical characteristics of the Pd$\mathrm{Au}$, as well as the $\mathrm{Au}$ and Pd nanoelectrodes synthesized by DENA are shown in Table S1 and Figures S7 and S8. Pd-Au nanowires demonstrate a wide linear range and a lower limit of detection than Pd and $\mathrm{Au}$ nanowires, respectively. Sensitivity was found to be much higher for the $\mathrm{Pd}-\mathrm{Au}$ nanowires in comparison with the $\mathrm{Au}\left(5.7 \times 10^{-7} \mathrm{~A} \mathrm{M}^{-1}\right)$ and $\mathrm{Pd}\left(5.4 \times 10^{-7} \mathrm{~A} \mathrm{M}^{-1}\right)$ nanowires. For comparison, $\mathrm{Au} / \mathrm{Pd}$ suprananoparticles were obtained by Pd crystal growth on a Au nanoparticle surface and the results of the $\mathrm{H}_{2} \mathrm{O}_{2}$ detection on the GCE modified by these NPs were provided [63]. Huang et al. [63] provided measurements of $\mathrm{H}_{2} \mathrm{O}_{2}$ at (-0.05) V, which agree with our results on the $\mathrm{H}_{2} \mathrm{O}_{2}$ reduction potential setting. The linear range of $\mathrm{H}_{2} \mathrm{O}_{2}$ detection for the $\mathrm{Au} / \mathrm{Pd}$ suprananoparticles was from $1 \mu \mathrm{M}$ to $10 \mathrm{mM}$, which is close to that of the Pd-Au nanowires synthesized by DENA in the present work. A lower limit of $\mathrm{H}_{2} \mathrm{O}_{2}$ detection for the Pd-Au nanowires synthesized by DENA in the present work was obtained in comparison with literature data: $1 \mu \mathrm{M}$ [63], $1.6 \mu \mathrm{M}$ [64]. Thus, using a non-enzymatic $\mathrm{H}_{2} \mathrm{O}_{2}$ detection scheme, hydrogen peroxide can be detected with a high sensitivity and lower detection limit with the Pd-Au nanowires synthesized by DENA in the present work than with other noble metal nanostructures reviewed in [26,27]. Analytical performance of the proposed sensors is also compared with a number of previously reported sensors in Table 3. The DENA-prepared sensors in the present work offer a low detection limit, wide linear concentration interval as well as the additional advantages of high flexibility of materials and spatial resolution. While preparation of many sensors employs drop-casting or other immobilization procedures on GCE, the DENA sensors in our work imply no surface modification or residual surfactants from the chemical synthesis of nanostructures, which makes these sensors stable to the detachment of components and suitable for the cell culture conditions. Moreover, a significantly lower absolute value of the detection potential than in many previous studies [26,27,64,65] and Table 3 demonstrates that the DENA-grown Pd-Au nanodendrites are active with respect to the electrochemical reduction of $\mathrm{H}_{2} \mathrm{O}_{2}$. For the first time, we characterized $\mathrm{Pd}, \mathrm{Au}$, and $\mathrm{Pd}-\mathrm{Au}$ nanowires prepared by the DENA technique for analytical purposes in solutions.

Table 3 Analytical parameters of different $\mathrm{H}_{2} \mathrm{O}_{2}$ electrochemical sensors ${ }^{\mathrm{a}}$

\begin{tabular}{lccccc}
\hline $\begin{array}{l}\text { Electrode } \\
\text { material }\end{array}$ & $\begin{array}{c}\text { Applied } \\
\text { potential/ V }\end{array}$ & $\begin{array}{c}\text { Linear range/ } \\
\mathrm{M}\end{array}$ & $\begin{array}{c}\text { Detection } \\
\text { limit } / \mathrm{M}\end{array}$ & Sensitivity & Ref \\
\hline $\mathrm{Ag} / \mathrm{PMo12} / \mathrm{PA} / \mathrm{G}$ & $0.0(\mathrm{Ag} / \mathrm{AgCl}$, & $(2-20) \times 10^{-6}$ & $0.75 \times 10^{-6}$ & 4.398 & {$[66]$} \\
$\mathrm{CE}^{\mathrm{b}}$ & $\left.1.0 \mathrm{M} \mathrm{H}_{2} \mathrm{SO}_{4}\right)$ & & & $\mathrm{nA} \mathrm{\mu M}^{-1}$ & \\
$\mathrm{PEDOTPSS}^{-}$ & -0.15 & $(5-120) \times 10^{-6}$ & $0.1 \times 10^{-6}$ & 353.9 & {$[67]$} \\
$\mathrm{MDB} / G C E^{\mathrm{c}}$ & $(\mathrm{Ag} / \mathrm{AgCl})$ & & & $\mu \mathrm{A} \mathrm{mM} \mathrm{cm}^{-2}$ &
\end{tabular}




\begin{tabular}{|c|c|c|c|c|c|}
\hline Co CLDH/GCE ${ }^{\mathrm{d}}$ & $\begin{array}{l}-0.416 \text { (SCE, } \\
0.1 \mathrm{M} \mathrm{NaOH})\end{array}$ & $\begin{array}{c}1 \times 10^{-5}- \\
1.1 \times 10^{-3}\end{array}$ & $2.0 \times 10^{-6}$ & $\begin{array}{c}44.37 \\
\mu \mathrm{AM}^{-1}\end{array}$ & [68] \\
\hline $\begin{array}{l}\text { Chit- } \\
\text { MWNTs/Hb/Ag } \\
\text { NPs/GCE }^{\mathrm{e}}\end{array}$ & $\begin{array}{c}-0.3 \\
(\mathrm{Ag} / \mathrm{AgCl}, 3 \mathrm{M} \\
\mathrm{KCl})\end{array}$ & $\begin{array}{l}6.25 \times 10^{-6}- \\
9.30 \times 10^{-5}\end{array}$ & $3.47 \times 10^{-7}$ & - & [69] \\
\hline $\begin{array}{l}\mathrm{HRP} / \gamma- \\
\mathrm{Al} 2 \mathrm{O} 3 / \mathrm{CHT} / \\
\mathrm{GCE}^{\mathrm{f}}\end{array}$ & 0 (SCE) & $\underset{6}{(0.5-700) \times 10^{-}}$ & $0.07 \times 10^{-6}$ & $\begin{array}{c}0.249 \\
\mathrm{~A} \mathrm{M}^{-1} \mathrm{~cm}^{-2}\end{array}$ & [70] \\
\hline $\begin{array}{l}\text { Ag NPs/CHIT- } \\
\text { GO/cysteamine/A } \\
\text { u electrode }\end{array}$ & -0.4 (SCE) & $\begin{array}{l}6.0 \times 10^{-6}- \\
18.0 \times 10^{-3}\end{array}$ & $0.7 \times 10^{-6}$ & $\begin{array}{c}0.0624 \\
\mu \mathrm{A} \mu \mathrm{M}^{-1}\end{array}$ & [71] \\
\hline $\begin{array}{l}\mathrm{Hb} \text { entrapped in } \\
\mathrm{ZnO} / \mathrm{SnO}_{2}-\mathrm{Chi} \\
\text { composite } \\
\text { film/GCE }{ }^{\mathrm{h}}\end{array}$ & $\begin{array}{c}-0.3 \\
\text { (sat. } \mathrm{Ag} / \mathrm{AgCl} \text { ) }\end{array}$ & $\begin{array}{l}2.0 \times 10^{-6}- \\
3.7 \times 10^{-4}\end{array}$ & $4.6 \times 10^{-7}$ & $\begin{array}{c}52.8 \\
\mathrm{~mA} \mathrm{M} \mathrm{M}^{-1} \mathrm{~cm}^{-2}\end{array}$ & [72] \\
\hline $\begin{array}{l}\mathrm{Hb}^{\mathrm{i}} \text { on the } \\
\text { graphene/ } \\
\mathrm{Fe}_{3} \mathrm{O}_{4-} \\
\text { nanocomposie/G } \\
\mathrm{CE}\end{array}$ & - & $\begin{array}{c}0.25 \times 10^{-6}- \\
1.7 \times 10^{-3}\end{array}$ & $6.0 \times 10^{-6}$ & - & [73] \\
\hline $\begin{array}{l}\text { Electrodeposited } \\
\mathrm{Ag} \\
\mathrm{NP} / \mathrm{MWCNT} / \mathrm{G} \\
\mathrm{CE}^{\mathrm{j}}\end{array}$ & $\begin{array}{c}\text { about }-0.6 \\
\text { (sat. } \mathrm{Ag} / \mathrm{AgCl} \text { ) }\end{array}$ & $(0.1-10) \times 10^{-3}$ & $2 \times 10^{-6}$ & $\begin{array}{c}9.79 \\
\mu \mathrm{A} \mathrm{mM^{-1 }} \mathrm{mm}^{-2}\end{array}$ & [74] \\
\hline $\begin{array}{l}\text { HRP/PANI/PEG- } \\
\text { MWCNT } \\
\text { nanocomposite/A } \\
\text { u electrode }^{\mathrm{k}}\end{array}$ & $-0.1(\mathrm{Ag} / \mathrm{AgCl})$ & $\begin{array}{c}(4.98- \\
43.10) \times 10^{-6}\end{array}$ & $0.5 \times 10^{-6}$ & $\begin{array}{c}1.01 \\
\mu \mathrm{A} \mathrm{L} \mathrm{cm}{ }^{-2} \mu \mathrm{M}^{-1}\end{array}$ & [75] \\
\hline $\begin{array}{l}\text { Nf/(HRP-f- } \\
\text { graphene-Ag)/Gr }{ }^{1}\end{array}$ & -0.5 (SCE) & $\begin{array}{c}25 \times 10^{-6}- \\
19.35 \times 10^{-3}\end{array}$ & $5 \times 10^{-6}$ & 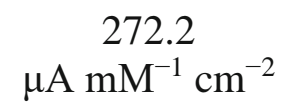 & [76] \\
\hline $\begin{array}{l}\text { AuNPs/AET/GW } \\
/ \text { PB }^{\mathrm{m}}\end{array}$ & -0.1 (SCE) & $\begin{array}{c}(0.05- \\
7.800) \times 10^{-6}\end{array}$ & $0.015 \times 10^{-6}$ & $\begin{array}{c}23.58 \\
\mu \mathrm{A} \mathrm{mM}\end{array}$ & [77] \\
\hline $\begin{array}{l}\mathrm{Ni}(\mathrm{OH})_{2-} \\
\mathrm{NiOOH} / \mathrm{Pt} / \mathrm{n}-\mathrm{n}+- \\
\mathrm{Si}^{{ }^{\mathrm{n}}}\end{array}$ & $\begin{array}{c}0 \\
(0.2 \mathrm{M} \mathrm{KOH})\end{array}$ & $\begin{array}{c}(0.02- \\
0.16) \times 10^{-3}\end{array}$ & $5.4 \times 10^{-6}$ & $\begin{array}{c}96.9 \\
\mu \mathrm{A} \mathrm{mM^{-1 }} \mathrm{cm}^{-2}\end{array}$ & [11] \\
\hline $\begin{array}{l}\text { Au-Pd supra- } \\
\text { nanoparticles/GC } \\
\text { E }\end{array}$ & $\begin{array}{c}\quad-0.05 \\
\text { (sat. } \mathrm{Ag} / \mathrm{AgCl} \text { ) }\end{array}$ & $\begin{array}{l}1 \times 10^{-6}- \\
10 \times 10^{-3}\end{array}$ & $1 \times 10^{-6}$ & $\begin{array}{l}17.4 \text { or } 27 \\
\mu \mathrm{AmM} \mathrm{mM}^{-1}\end{array}$ & [63] \\
\hline CNTs/GCE & $\begin{array}{c}-0.20 \\
\left(\mathrm{Hg} / \mathrm{Hg}_{2} \mathrm{SO}_{4}\right)\end{array}$ & - & $20 \times 10^{-6}$ & $\begin{array}{c}100 \\
\mathrm{~mA} \mathrm{M}^{-1} \mathrm{~cm}^{-2}\end{array}$ & [64] \\
\hline $\begin{array}{l}\mathrm{MnO}_{2} \text {-ERGO } \\
\text { paper }^{\circ}\end{array}$ & -0.5 (SCE) & $\begin{array}{c}(0.1- \\
45.4) \times 10^{-3}\end{array}$ & $10 \times 10^{-6}$ & $\begin{array}{c}59.0 \\
\mathrm{~mA} \mathrm{~cm}^{-2} \mathrm{mM}^{-1}\end{array}$ & [65] \\
\hline $\mathrm{Pd} / \mathrm{Au}$ NW & $\begin{array}{c}-0.05 \\
(\mathrm{Ag} / \mathrm{AgCl}, 3 \mathrm{M} \\
\mathrm{KCl}))\end{array}$ & $10^{-6}-10^{-3}$ & $3 \times 10^{-7}$ & $\begin{array}{c}18 \\
\mu \mathrm{A} \mathrm{M}^{-1}\end{array}$ & $\begin{array}{l}\text { This } \\
\text { work }\end{array}$ \\
\hline
\end{tabular}

\footnotetext{
${ }^{a}$ The number of significant figures in the numerical values in Table 3 is given as it is presented by the authors in the corresponding articles, GCE - the glassy carbon electrode, SCE - the saturated calomel electrode; b Hybrid silver/phosphophomolybdate/polyaniline on GCE; ${ }^{c}$ Poly(3,4-ethylene dioxythiophene)-poly(4-styrene sulfonate)-Meldola Blue; ${ }^{\mathrm{d}}$ cobalt containing calcined layered double hydroxide; ${ }^{\mathrm{e}}$ chitosan (Chit)-multiwalled carbon nanotubes (MWNTs)/silver nanoparticles (AgNPs)-hemoglobin (Hb) nanocomposite film; ${ }^{\mathrm{f}}$ horseradish peroxidase (HRP) and $\gamma-\mathrm{Al}_{2} \mathrm{O}_{3} /$ chitosan $(\mathrm{CHT}$ ) composite film at a GCE; ${ }^{g}$ silver nanoparticles (Ag NPs)/chitosan-graphene oxide (CHIT-GO)/cysteamine/Au electrode; ${ }^{\mathrm{h}}$
} 
hemoglobin $(\mathrm{Hb})$ and chitosan $(\mathrm{Chi}) ;{ }^{i}$ hemoglobin $(\mathrm{Hb}) ;{ }^{\mathrm{j}}$ multiwalled carbon nanotube MWCNT; ${ }^{\mathrm{k}}$ Horseradish peroxidase (HRP)/Polyaniline (PANI)/O,O-bis (2-aminoethyl) polyethyleneglycol (PEG)/multiwalled carbon nanotube (MWCNT); ${ }^{1}$ Horseradish peroxidase (HRP)/flower-like silver nanoparticles particles; $m$ Prussian blue (PB) film-modified 2aminoethanethiol (AET)-capped AuNPs (AuNPs)-graphite-wax (GW) composite electrode; ${ }^{\mathrm{n}}$ Photoelectrochemical sensor; ${ }^{\circ}$ ETGO - electrochemically reduced graphene oxide

The biocompatibility and biological application of the Pd-Au nanowire electrodes prepared by the DENA technique is further demonstrated by the experiments on the HL-1 cell response to hypoxia conditions. HL-1 cells are cardiomyocyte-like cells derived from a mouse atrial tumor [42]. As such, they are expected to respond similarly to other ischemia/reperfusion systems when oxygen is re-supplied after deprivation. This normally leads to an increase in $\mathrm{H}_{2} \mathrm{O}_{2}$ levels as the electron transport chain re-starts. HL-1 cells were plated at 94,500 cells per chip and cultured on the array of the polyimide-isolated Pd-Au nanodendrite electrodes for one to two days before measuring in PBS + glucose ( $\mathrm{NaCl} 137 \mathrm{mM}, \mathrm{KCl} 2.7$ $\mathrm{mM}, \mathrm{Na}_{2} \mathrm{HPO}_{4} 8 \mathrm{mM}, \mathrm{KH}_{2} \mathrm{PO}_{4} 1.8 \mathrm{mM}+$ glucose). The chip was equipped with a glass funnel as a reservoir to accommodate the cell culture medium (see Supporting Information for details). 2-day-old cell cultures were washed with PBS + glucose (see Supporting Information) and chronoamperograms at the Pd-Au nanodendrite electrodes were recorded in $100 \mu \mathrm{L}$ background solution (PBS + glucose). The solution was then deoxygenated with Ar for 5 min to simulate oxygen depletion conditions. Next, this solution was purged by air for $60 \mathrm{~s}$. After that, $-0.15 \mathrm{~V}$ was applied to the Pd-Au nanodendrite electrodes during 120 seconds and the current signal was recorded. This procedure was repeated to increase the effect of the hypoxia conditions, Figure 5. The detection potential was set according to the CV measurements of the background solution with the Pd-Au nanodendrite electrodes. Therefore, the detection potential shifted from $-0.05 \mathrm{~V}$ to $-0.15 \mathrm{~V}$ for measurements in the PBS + glucose. To examine the HL-1 cells after experiments, calcein-AM in growth medium was added to the culture (see experimental section for detail). This dye fluoresces green when metabolized by living cells. As shown in Figure 5, the cells were still alive after electrochemical experiments under hypoxic conditions. This provides evidence that the measured signals originate from the increased production of $\mathrm{H}_{2} \mathrm{O}_{2}$ during reperfusion rather than from apoptotic pathways. Experiments with catalase, a scavenger of $\mathrm{H}_{2} \mathrm{O}_{2}$, added to the measurement solution failed to produce increase of the cathodic current as without addition of catalase to the measurement solution under the same experimental conditions.

We quantified the $\mathrm{H}_{2} \mathrm{O}_{2}$ level after hypoxia periods by the standard addition method. For this, the known concentrations of $\mathrm{H}_{2} \mathrm{O}_{2}$ were added to the measured solution after hypoxia experiments and the concentrations of $\mathrm{H}_{2} \mathrm{O}_{2}$ produced after anaerobic periods were calculated, Table 4. ROS levels in HL-1 cells are higher than in other cell types due to the high number of mitochondria in cardiomyocytes. Even higher intracellular concentrations of $\mathrm{H}_{2} \mathrm{O}_{2}$ of $5 \mathrm{mM}$ have been reported [13]. Growing evidence suggests that the specific levels of ROS in cells may play a critical role in determining whether protective or 
apoptotic pathways are induced [78]. Furthermore, an increase in energy demand from a cell, such as in cancer, can cause an increase in ROS production. This shows the importance of spatial specificity and quantitative detection of $\mathrm{H}_{2} \mathrm{O}_{2}$ in the diagnostic device.
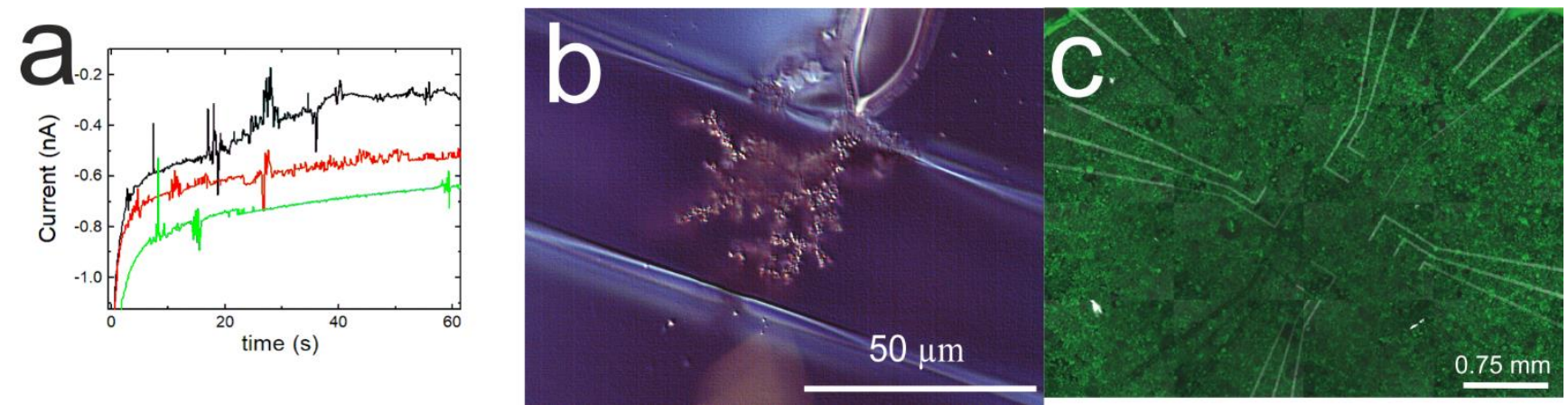

Fig. 5 a Chronoamperograms at the Pd-Au nanodendrite working electrode at $-0.15 \mathrm{~V}$ in the experiments on HL-1 cell response to hypoxia/reoxygenation conditions. The black line is the chronoamperogram in a background solution ( $\mathrm{NaCl} 137 \mathrm{mM}, \mathrm{KCl} 2.7 \mathrm{mM}, \mathrm{Na}_{2} \mathrm{HPO}_{4} 8 \mathrm{mM}, \mathrm{KH}_{2} \mathrm{PO}_{4} 1.8 \mathrm{mM}+$ glucose), red line - after $5 \mathrm{~min}$ of anaerobic conditions and reoxygenation, green line - after 10 min of anaerobic conditions and reoxygenation. b Image of the $\mathrm{Pd}-\mathrm{Au}$ nanodendrite electrode which was used for the experiments with cell culture. c An optical microscope image of the HL-1 cells with calcein-AM added to the culture after electrochemical experiments on hypoxia/reoxygenation conditions

Table 4 Results of the method of standard additions after HL-1 hypoxia measurements

\begin{tabular}{cccc}
\hline Solution & \multicolumn{2}{c}{ For sensor on Fig. 5b } & $\begin{array}{c}\text { Average value and } \\
\text { confidence limits for three } \\
\text { Pd-Au NW electrodes }\end{array}$ \\
& $\Delta I / \mathrm{A}$ & $C / \mathrm{M}$ & $C \pm \Delta C / \mathrm{M}$ \\
\hline 5 min hypoxia & $-6.3 \times 10^{-10}$ & $2.9 \times 10^{-4}$ & $(2.7 \pm 0.3) \times 10^{-4}$ \\
10 min hypoxia & $-7.8 \times 10^{-10}$ & $3.0 \times 10^{-4}$ & $(3.1 \pm 0.3) \times 10^{-4}$ \\
1st standard & $-4.0 \times 10^{-9}$ & $5.2 \times 10^{-4}$ & $(5.6 \pm 0.4) \times 10^{-4}$ \\
addition & & & \\
2nd standard & $-1.2 \times 10^{-8}$ & $1.1 \times 10^{-3}$ & $(1.2 \pm 0.1) \times 10^{-3}$ \\
addition & & &
\end{tabular}

\footnotetext{
${ }^{a}$ Found for three Pd-Au NW electrodes on the same chip and under the same cell culture conditions, $\mathrm{n}=3$, where $\mathrm{n}$ is the number of the nanowire electrodes, and the confidence level is 0.95 .
}

\section{Conclusions}


In conclusion, we developed conditions for DENA to prepare nanowires and nanodendrites of various metals and their alloys connected with external circuitry on a single chip and assembled them to create functional sensor devices for electrolyte solutions. SEM analysis of the nanostructured electrodes demonstrated that the diameters of the nanostructures were within a range of 50 to $800 \mathrm{~nm}$. Current voltage characteristics of the nanostructures demonstrated perfect connections between circuitry points on chips provided by the nanointerconnections. The nanostructures were further characterized by EDX and element map analysis. We show that the prepared nanostructures of various compositions can be addressed individually for use in electrolyte solutions as functional devices. The sensor application of these devices in electrolytes and cell culture conditions has been demonstrated for the first time. For example, $\mathrm{Pd}-\mathrm{Au}$ nanowires were applied for a non-enzymatic assay of $\mathrm{H}_{2} \mathrm{O}_{2}$ with the following sensor characteristics:

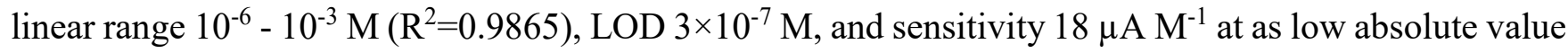
of the detection potential as $-0.05 \mathrm{~V}$. Biological application is further demonstrated with the hypoxia experiments in the HL-1 cell culture. The arrayed nanowires of various materials in one device were prepared without using the multiple steps of the lithographic process for different compositions. We further propose that the nanostructures of metals and metal alloys prepared by DENA techniques can be widely used in the fields of micro- and nanoelectronics, catalysis, microfuel cells, and multisensor devices to realize the synergetic effects of electrocatalytic materials.

\section{Acknowledgements}

Grant (grant number 12.38.218.2015) from St. Petersburg State University is acknowledged for electrochemical studies. KN was supported by DAAD (Migration Mendeleev Forschungsstip. grant number 50024759). Thanks are due to M. Prömpers, E. Brauweiler-Reuters, Dr. A. Savenko for support with photolithography processes and structural analysis.

\section{References}

1. Chance B, Sies H, Boveris A (1979) Hydroperoxide metabolism in mammalian organs. Physiological Reviews 59 (3):527

2. Sedensky MM, Morgan PG (2006) Mitochondrial respiration and reactive oxygen species in mitochondrial aging mutants. Experimental Gerontology 41 (3):237-245.

3. Amatore C, Arbault S. (2007) Oxidative Stress at the Single Cell Level. In: Michael A.C., Borland L.M. (eds) Electrochemical Methods for Neuroscience. CRC Press/Taylor \& Francis, Boca Raton (FL), p 261

4. Veal EA, Day AM, Morgan BA (2007) Hydrogen Peroxide Sensing and Signaling. Molecular Cell 26 (1):1-14.

5. Calas-Blanchard C, Catanante G, Noguer T (2014) Electrochemical Sensor and Biosensor Strategies for ROS/RNS Detection in Biological Systems. Electroanalysis 26 (6):1277-1286.

6. Bachi A, Dalle-Donne I, Scaloni A (2013) Redox Proteomics: Chemical Principles, Methodological Approaches and Biological/Biomedical Promises. Chemical Reviews 113 (1):596-698. 
7. Merksamer PI, Liu Y, He W, Hirschey MD, Chen D, Verdin E (2013) The sirtuins, oxidative stress and aging: An emerging link. Aging 5 (3):144-150

8. Finkel T, Holbrook NJ (2000) Oxidants, oxidative stress and the biology of ageing. Nature 408 (6809):239-247

9. Crulhas BP, Ramos NP, Castro GR, Pedrosa VA (2016) Detection of hydrogen peroxide releasing from prostate cancer cell using a biosensor. Journal of Solid State Electrochemistry 20 (9):2427-2433.

10. Koposova E, Liu X, Kisner A, Ermolenko Y, Shumilova G, Offenhäusser A, Mourzina Y (2014) Bioelectrochemical systems with oleylamine-stabilized gold nanostructures and horseradish peroxidase for hydrogen peroxide sensor. Biosensors and Bioelectronics 57:54-58.

11. Hao W-L, Li H-X, Shen C-Y, Liu S-L (2014) Nickel oxide hydroxide/platinum double layers modified n-silicon electrode for hydrogen peroxide determination. Journal of Solid State Electrochemistry 18 (4):1041-1047.

12. Koposova E, Shumilova G, Ermolenko Y, Kisner A, Offenhäusser A, Mourzina Y (2015) Direct electrochemistry of cyt $\mathrm{c}$ and hydrogen peroxide biosensing on oleylamine- and citrate-stabilized gold nanostructures. Sensors and Actuators B-Chemical 207:1045-1052.

13. Arbault S, Pantano P, Jankowski JA, Vuillaume M, Amatore C (1995) Monitoring an oxidative stress mechanism at a single human fibroblast. Analytical Chemistry 67 (19):3382-3390.

14. Jaime-González J, Mazario E, Menendez N, Sanchez-Marcos J, Muñoz-Bonilla A, Herrasti P (2016) Comparison of ferrite nanoparticles obtained electrochemically for catalytical reduction of hydrogen peroxide. Journal of Solid State Electrochemistry 20 (4):1191-1198.

15. Zhang R, Chen W (2017) Recent advances in graphene-based nanomaterials for fabricating electrochemical hydrogen peroxide sensors. Biosensors and Bioelectronics 89, Part 1:249-268.

16. Xiao F, Wang L, Duan H (2016) Nanomaterial based electrochemical sensors for in vitro detection of small molecule metabolites. Biotechnology Advances 34 (3):234-249.

17. Kondratiev VV, Pogulaichenko NA, Tolstopjatova EG, Malev VV (2011) Hydrogen peroxide electroreduction on composite PEDOT films with included gold nanoparticles. Journal of Solid State Electrochemistry 15 (11):2383-2393.

18. Marquitan M, Clausmeyer J, Actis P, Córdoba AL, Korchev Y, Mark MD, Herlitze S, Schuhmann W (2016) Intracellular Hydrogen Peroxide Detection with Functionalised Nanoelectrodes. ChemElectroChem 3 (12):2125-2129.

19. Sitnikova NA, Komkova MA, Khomyakova IV, Karyakina EE, Karyakin AA (2014) Transition Metal Hexacyanoferrates in Electrocatalysis of H2O2 Reduction: An Exclusive Property of Prussian Blue. Analytical Chemistry 86 (9):4131-4134.

20. Yamada Y, Yoshida S, Honda T, Fukuzumi S (2011) Protonated iron-phthalocyanine complex used for cathode material of a hydrogen peroxide fuel cell operated under acidic conditions. Energy \& Environmental Science 4 (8):2822-2825.

21. Wei Z, Xiaochuan D, Lieber CM (2017) Advances in nanowire bioelectronics. Reports on Progress in Physics 80 (1):016701

22. Zhu N, Han S, Gan S, Ulstrup J, Chi Q (2013) Graphene Paper Doped with Chemically Compatible Prussian Blue Nanoparticles as Nanohybrid Electrocatalyst. Advanced Functional Materials 23 (42):5297-5306.

23. Nikolaev K, Ermakov S, Ermolenko Y, Averyaskina E, Offenhäusser A, Mourzina Y (2015) A novel bioelectrochemical interface based on in situ synthesis of gold nanostructures on electrode surfaces and surface activation by Meerwein's salt. A bioelectrochemical sensor for glucose determination. Bioelectrochemistry 105:34-43.

24. Ermakov SS, Nikolaev KG, Tolstoi VP (2016) Novel electrochemical sensors with electrodes based on multilayers fabricated by layer-by-layer synthesis and their analytical potential. RUSS CHEM REV 85:880-900.

25. Zhang A, Lieber CM (2016) Nano-Bioelectronics. Chemical Reviews 116 (1):215-257.

26. Chen S, Yuan R, Chai Y, Hu F (2013) Electrochemical sensing of hydrogen peroxide using metal nanoparticles: a review. Microchimica Acta 180 (1-2):15-32. 
27. Chen XM, Wu GH, Cai ZX, Oyama M, Chen X (2014) Advances in enzyme-free electrochemical sensors for hydrogen peroxide, glucose, and uric acid. Microchimica Acta 181 (7-8):689-705.

28. Flanders BN, Talukdar I, Ozturk B, Thapa P (United States Patent 8137526, 2012) Method of making an electrochemical nanowire assembly and attaching cells thereto. United States Patent,

29. Talukdar I, Ozturk B, Flanders BN, Mishima TD (2006) Directed growth of single-crystal indium wires. Applied Physics Letters 88 (22):221907.

30. Yi X, Yu G, Chang F, Xie ZH, Tran TN, Hu BN, Zhong C-J (2014) Electrochemically Controlled Growth of Au $\square$ Pt Alloy Nanowires and Nanodendrites. Chemistry - An Asian Journal 9 (9):2612-2620. 31. Zhang M, Yang X, Zhou Z, Ye X (2013) Controllable growth of gold nanowires and nanoactuators via high-frequency AC electrodeposition. Electrochemistry Communications 27:133-136.

32. Cheng C, Gonela RK, Gu Q, Haynie DT (2005) Self-Assembly of Metallic Nanowires from Aqueous Solution. Nano Letters 5 (1):175-178.

33. Kawasaki JK, Arnold CB (2011) Synthesis of Platinum Dendrites and Nanowires Via Directed Electrochemical Nanowire Assembly. Nano Letters 11 (2):781-785.

34. Ozturk B, Bret NF, Daniel RG, Tetsuya DM (2007) Single-step growth and low resistance interconnecting of gold nanowires. Nanotechnology 18 (17):175707

35. Ozturk B, Talukdar I, Bret NF (2007) Directed growth of diameter-tunable nanowires. Nanotechnology 18 (36):365302

36. Ji J, Zhou Z, Yang X, Zhang W, Sang S, Li P (2013) One-Dimensional Nano-Interconnection Formation. Small 9 (18):3014-3029.

37. Xiang C, Kung S-C, Taggart DK, Yang F, Thompson MA, Güell AG, Yang Y, Penner RM (2008) Lithographically Patterned Nanowire Electrodeposition: A Method for Patterning Electrically Continuous Metal Nanowires on Dielectrics. ACS Nano 2 (9):1939-1949.

38. Favier F, Walter EC, Zach MP, Benter T, Penner RM (2001) Hydrogen Sensors and Switches from Electrodeposited Palladium Mesowire Arrays. Science 293 (5538):2227-2231.

39. Murray BJ, Walter EC, Penner RM (2004) Amine Vapor Sensing with Silver Mesowires. Nano Letters 4 (4):665-670.

40. Ksar F, Ramos L, Keita B, Nadjo L, Beaunier P, Remita H (2009) Bimetallic Palladium-Gold Nanostructures: Application in Ethanol Oxidation. Chemistry of Materials 21 (15):3677-3683.

41. Wang D, Villa A, Porta F, Prati L, Su D (2008) Bimetallic Gold/Palladium Catalysts: Correlation between Nanostructure and Synergistic Effects. The Journal of Physical Chemistry C 112 (23):8617-8622. 42. Claycomb WC, Lanson NA, Stallworth BS, Egeland DB, Delcarpio JB, Bahinski A, Izzo NJ (1998) HL-1 cells: A cardiac muscle cell line that contracts and retains phenotypic characteristics of the adult cardiomyocyte. Proceedings of the National Academy of Sciences of the United States of America 95 (6):2979-2984

43. White SM, Constantin PE, Claycomb WC (2004) Cardiac physiology at the cellular level: use of cultured HL-1 cardiomyocytes for studies of cardiac muscle cell structure and function. American Journal of Physiology - Heart and Circulatory Physiology 286 (3):H823-H829.

44. Nerowski A, Poetschke M, Bobeth M, Opitz J, Cuniberti G (2012) Dielectrophoretic Growth of Platinum Nanowires: Concentration and Temperature Dependence of the Growth Velocity. Langmuir 28 (19):7498-7504.

45. Ozturk B, Blackledge C, Flanders BN, Grischkowsky DR (2006) Reproducible interconnects assembled from gold nanorods. Applied Physics Letters 88 (7):073108.

46. Bangar MA, Ramanathan K, Yun M, Lee C, Hangarter C, Myung NV (2004) Controlled growth of a single palladium nanowire between microfabricated electrodes. Chemistry of Materials 16 (24):49554959.

47. Cheng Y, Yu G, Tang L, Zhou Y, Zhang G (2011) Self-assembled dendritic nanowires of Au-Pt alloy through electrodeposition from solution under AC fields. Journal of Crystal Growth 334 (1):181-188.

48. Ji J, Li P, Sang S, Zhang W, Zhou Z, Yang X, Dong H, Li G, Hu J (2014) Electrodeposition of Au/Ag bimetallic dendrites assisted by Faradaic AC-electroosmosis flow. AIP Advances 4 (3):031329. 
49. Tang LL, Yu G, Li XG, Chang FF, Zhong CJ (2015) Palladium-Gold Alloy Nanowire-Structured Interface for Hydrogen Sensing. Chempluschem 80 (4):722-730.

50. Bockris JOM, Reddy AKN, Gamboa-Aldeco ME (2001) Modern Electrochemistry 2A: Fundamentals of Electrodics. Springer US,

51. Nerowski A, Opitz J, Baraban L, Cuniberti G (2013) Bottom-up synthesis of ultrathin straight platinum nanowires: Electric field impact. Nano Research 6 (5):303-311.

52. Harper CA (1997) Passive Electronic Component Handbook. McGraw-Hill.

53. Mroczkowski RS (1998) Electronic Connector Handbook: Theory and Applications. McGraw-Hill.

54. Chen A, Ostrom C (2015) Palladium-Based Nanomaterials: Synthesis and Electrochemical Applications. Chemical Reviews 115 (21):11999-12044.

55. Trasatti S (1986) The absolute electrode potential: an explanatory note (Recommendations 1986). Pure and Applied Chemistry, vol 58.

56. Pud S, Kisner A, Heggen M, Belaineh D, Temirov R, Simon U, Offenhäusser A, Mourzina Y, Vitusevich S (2013) Features of transport in ultrathin gold nanowire structures. Small 9 (6):846-852.

57. Muratova IS, Mikhelson KN, Ermolenko Y, Offenhäusser A, Mourzina Y (2016) On "resistance overpotential" caused by a potential drop along the ultrathin high aspect ratio gold nanowire electrodes in cyclic voltammetry. Journal of Solid State Electrochemistry 20 (12):3359-3365.

58. Arblaster JW (2015) Selected Electrical Resistivity Values for the Platinum Group of Metals Part I: Palladium and Platinum. Johnson Matthey Technology Review 59 (3):174-181.

59. Wissmann P, Finzel HU (2007) Electrical Resistivity of Thin Metal Films. vol Nr. 223. Springer, 60. Ustinova E, Gorchakov E, Kolpakova N (2012) Anodic stripping determination of Pt(IV) based on the anodic oxidation of In from electrochemically deposited Pt-In alloy phases. Journal of Solid State Electrochemistry 16 (7):2455-2458.

61. Wang H, Bo X, Bai J, Wang L, Guo L (2011) Electrochemical applications of platinum-palladium alloy nanoparticles/large mesoporous carbon. Journal of Electroanalytical Chemistry 662 (2):281-287.

62. Zhou P, Dai Z, Fang M, Huang X, Bao J, Gong J (2007) Novel Dendritic Palladium Nanostructure and Its Application in Biosensing. The Journal of Physical Chemistry C 111 (34):12609-12616.

63. Huang Y, Ferhan AR, Dandapat A, Yoon CS, Song JE, Cho EC, Kim D-H (2015) A Strategy for the Formation of Gold-Palladium Supra-Nanoparticles from Gold Nanoparticles of Various Shapes and Their Application to High-Performance H2O2 Sensing. The Journal of Physical Chemistry C 119 (46):2616426170.

64. Goran JM, Phan ENH, Favela CA, Stevenson KJ (2015) H2O2 Detection at Carbon Nanotubes and Nitrogen-Doped Carbon Nanotubes: Oxidation, Reduction, or Disproportionation? Analytical Chemistry 87 (12):5989-5996.

65. Dong S, Xi J, Wu Y, Liu H, Fu C, Liu H, Xiao F (2015) High loading MnO2 nanowires on graphene paper: Facile electrochemical synthesis and use as flexible electrode for tracking hydrogen peroxide secretion in live cells. Analytica Chimica Acta 853:200-206.

66. Manivel A, Anandan S (2011) Silver nanoparticles embedded phosphomolybdate-polyaniline hybrid electrode for electrocatalytic reduction of H2O2. Journal of Solid State Electrochemistry 15 (1):153-160. 67. Siao H-W, Chen S-M, Lin K-C (2011) Electrochemical study of PEDOT-PSS-MDB-modified electrode and its electrocatalytic sensing of hydrogen peroxide. Journal of Solid State Electrochemistry 15 (6):1121-1128.

68. Wang J, Cui L, Yin H, Dong J, Ai S (2012) Determination of hydrogen peroxide based on calcined layered double hydroxide-modified glassy carbon electrode in flavored beverages. Journal of Solid State Electrochemistry 16 (4):1545-1550.

69. Li Y, Li Y, Yang Y (2012) A new amperometric H2O2 biosensor based on nanocomposite films of chitosan-MWNTs, hemoglobin, and silver nanoparticles. Journal of Solid State Electrochemistry 16 (3):1133-1140.

70. Liu X, Luo L, Ding Y, Xu Y, Li F (2011) Hydrogen peroxide biosensor based on the immobilization of horseradish peroxidase on $\gamma$-A12O3 nanoparticles/chitosan film-modified electrode. Journal of Solid State Electrochemistry 15 (3):447-453. 
71. Wang L, Zhu H, Hou H, Zhang Z, Xiao X, Song Y (2012) A novel hydrogen peroxide sensor based on Ag nanoparticles electrodeposited on chitosan-graphene oxide/cysteamine-modified gold electrode. Journal of Solid State Electrochemistry 16 (4):1693-1700.

72. Wu R, Chen X, Hu J (2012) Synthesis, characterization, and biosensing application of $\mathrm{ZnO} / \mathrm{SnO} 2$ heterostructured nanomaterials. Journal of Solid State Electrochemistry 16 (5):1975-1982.

73. Wang Y, Zhang H, Yao D, Pu J, Zhang Y, Gao X, Sun Y (2013) Direct electrochemistry of hemoglobin on graphene/Fe3O4 nanocomposite-modified glass carbon electrode and its sensitive detection for hydrogen peroxide. Journal of Solid State Electrochemistry 17 (3):881-887.

74. Afraz A, Rafati AA, Hajian A (2013) Analytical sensing of hydrogen peroxide on Ag nanoparticlesmultiwalled carbon nanotube-modified glassy carbon electrode. Journal of Solid State Electrochemistry 17 (7):2017-2025.

75. da Silva JV, Pimentel DM, Souto DEP, de Cássia Silva Luz R, Damos FS (2013) Application of horseradish peroxidase/polyaniline/bis(2-aminoethyl) polyethylene glycol-functionalized carbon nanotube composite as a platform for hydrogen peroxide detection with high sensitivity at low potential. Journal of Solid State Electrochemistry 17 (11):2795-2804.

76. Nalini S, Nandini S, Shanmugam S, Neelagund SE, Melo JS, Suresh GS (2014) Amperometric hydrogen peroxide and cholesterol biosensors designed by using hierarchical curtailed silver flowers functionalized graphene and enzymes deposits. Journal of Solid State Electrochemistry 18 (3):685-701. 77. Prabhu P, Babu RS, Narayanan SS (2014) Synergetic effect of Prussian blue film with gold nanoparticle graphite-wax composite electrode for the enzyme-free ultrasensitive hydrogen peroxide sensor. Journal of Solid State Electrochemistry 18 (4):883-891.

78. Liou G-Y, Storz P (2010) Reactive oxygen species in cancer. Free Radical Research 44 (5):479-496. 